\title{
FEDERAL ACTIVITY IN ALCOHOLIC BEVERAGE CONTROL
}

\author{
Jorn E. O'NeILI*
}

The alcoholic beverage industry, often referred to since repeal of the Eighteenth Amendment as "new born," was never a babe in swaddling clothes even at the moment of its inception. As it nears the age of seven, it towers in size over many of its older brothers who have long since reached maturity. Over I,229,000 persons, including proprietors and employees, derive their livelihood directly from the manufacture and sale of alcoholic beverages. ${ }^{1}$ There are operating in the United States approximately 280 distilleries, 600 breweries, I, I00 wineries, 250 rectifying plants, 14,000 wholesalers and 309,000 retail liquor establishments.

In an average year approximately three billion dollars is expended by the American consumer in purchasing distilled spirits, wines and malt beverages, one billion dollars of which goes to the federal, state and local governments in the form of miscellaneous taxes and licensing fees, one billion dollars into wages and salaries, and the remainder into raw materials, transportation, fuel, barrels, bottles, printing, advertising, and similar basic production costs, and into operating profits. ${ }^{2}$ The annual domestic consumption of alcoholic beverages, as indicated by federal tax payments, approximates 90 million gallons of distilled spirits, $7 \mathrm{x}$ million gallons of wine, and 52 million barrels of beer.

Federal receipts in internal revenue taxes and customs duties on alcoholic beverages amounted to $\$ 635,786,935.20$ in 1939 , out of a total federal, state and local revenue from these products of $\$ 1,010,384,672.86 .^{3}$ The industry ranked third among all industries in the total amount spent on newspaper advertising during 1939, and sixth in expenditures for advertising in the four media of newspapers, magazines, farm journals and chain radio. The r 939 advertising expenditure of the industry in these media exceeded 29 million dollars, and was surpassed only by expenditures for advertising of groceries, automobiles, toilet requisites, tobacco, and medical supplies. ${ }^{4}$

* LL.B., I920, LL.M., I921, Georgetown University. Member of the bar in New York and the District of Columbia. Technical Adviser to the Deputy Commissioner of Internal Revenue in Charge of the Alcohol Tax Unit, since July I, 1940. Occupant of various legal positions in the United States Trcasury Department for over twenty years, dealing exclusively with liquor control. Former Legal Adviser to Federal Prohibition Administrator for New York State; former Assistant General Counsel, Federal Alcohol Administration; recently Administrative Technical Assistant, Federal Alcohol Administration.

${ }^{1}$ Distilled Spirits Institute Release, April 25, r940.

"Id., Economic Statistics of the Distilling Industry (1940).

${ }^{3}$ Id., Public Revenues from Alcoholic Beverages 1939 (1940).

'Bureat of Adv'g of the Am. Newspaper Publishers Ass'n Rep., July, 1940. 
Including outdoor advertising, pamphlets, and point of sale advertising matter upon which is being expended annually an additional I3 million dollars the total annual advertising bill for alcoholic beverages is 42 million dollars.

The liquor industry is the most thoroughly regulated and carefully supervised of all industries. As time passes new ideas for making the control and supervision even more effective are being translated into federal, state and local laws and regulations. Seldom has there been any tendency to relax a control over the industry once acquired. The necessity for rigid control, from the revenue as well as the social standpoint, is indicated by the fact that the lawless element, from the time the first liquor tax was imposed, has competed with the legitimate industry for the consumers trade, with liquor of illicit production. This tendency on the part of persons not inclined to law observance, to compete with legitimate industry, has not been so noticeable where excise taxes are imposed on other commodities such as gasoline and tobacco, even though the tax rate, in proportion to the retail cost of the product, exceeds the tax rate on liquor. This is no doubt due to many considerations, including the ready availability of materials from which liquor can be produced, the relative simplicity of the process of manufacture, in which nature plays a large part, the comparatively high cost of the finished product, and the very nature of the product itself, as an intoxicant. The scope of illicit liquor operations is indicated by the fact that about I2,000 moonshine stills are seized and destroyed each year.5 During the fiscal year ended June $30,1940,18,05^{6}$ persons were convicted of liquor law violations. In the fiscal year 1939,42 percent of all federal prisoners committed to the penitentiary were liquor law violators. ${ }^{6}$ The protection of the legitimate industry from bootleg competition is essential from the revenue as well as the social point of view, and in consequence constitutes a large part of the federal picture of liquor control.

\section{Post-Repeal InNovations in Liquor Control}

\section{Establishment of the Federal Alcohol Control Administration}

The liquor problem was one of the first dealt with by Congress following the $193^{2}$ elections. Senate Joint Resolution 2Ir, proposing the Twenty-first Amendment to the Constitution, was passed by the Senate February 16, I933, and by the House of Representatives on February 20, 1933. Within ten months, on December 5, I933, upon the ratification of the amendment by the State of Utah, Repeal became an accomplished fact. In his repeal proclamation the President stated in part: " The policy of the Government will be to see to it that the social and political evils that have existed in the pre-prohibition era shall not be revived nor permitted again to exist. We must remove forever from our midst the menace of the bootlegger and such others as would profit at the expense of good government, law, and order."

The assumption by the Federal Government of some of the responsibility for

'Hearings before Subcommittee of the House Committee on Appropriations on Treasury Dep't Appro-

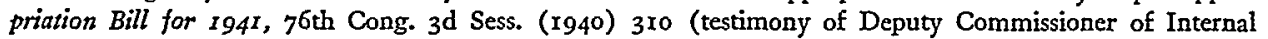
Revenue, Stewart Berkshire).

${ }^{0}$ Id. at 305 .

${ }^{7} 48$ Stat. I72I (I933). 
eliminating the "social and political evils" surrounding the liquor traffic paved the way to the adoption of new and novel federal regulations. Prior to Prohibition, federal liquor legislation was designed primarily for the protection of the revenue. Taxes were levied on the various occupations connected with the production and distribution of alcoholic beverages, and excise taxes were imposed upon the beverages produced. In consequence, the executive branch of the government, in the liquor field, devoted itself almost exclusively to the collection of the revenue and the apprehension and punishment of tax evaders.

As Congress was not in session at the time of Repeal, the code system established under the National Industrial Recovery Act, ${ }^{8}$ was viewed as a ready instrument to effectuate the new policy, until such time as Congress might enact specific legislation. Codes of fair competition were adopted for all branches of the industry, except retailers, and the Federal Alcohol Control Administration was created by executive order on December 4, 1933, to administer these codes. ${ }^{\circ}$ The various industries were organized into associations, and were represented by elected Code Authorities, which were vested with considerable authority to investigate and report code violations. The Federal Alcohol Control Administration applied the sanctions prescribed by these codes. The main purposes of the six alcoholic beverage codes were:

r. Protection of the consumer against deception from false and misleading labeling and advertising, and providing the consumer with adequate information as to the identity and characteristics of the product.

2. Prevention of unfair trade practices, such as commercial bribery, consignment and conditional sales, the control of retail outlets, furnishing of advertising, display or distribution service to trade buyers, guarantees against price decline, and furnishing of prizes, premiums, or gifts to trade or consumer buyers.

3. Prevention of shipments of intoxicating liquor into any state for delivery or use therein in violation of state law.

4. Prevention of sales of distilled spirits in bulk containers into wholesale, retail and consumer channels.

5. Limitation of production and importation of alcoholic beverages to the quantities necessary to meet consumer demands.

6. Price control, by establishing open price posting, preventing sales at prices not posted, and declaring ineffective posted prices which were oppressively high or destructively low.

Although the Federal Alcoholic Control Administration ceased to function on May 27, I935, when the National Industrial Recovery Act was declared unconstitutional by the Supreme Court in the Schechter case, ${ }^{10}$ most of the practices outlined above were made unlawful by the passage in August, 1935, of the Federal Alcohol Administration Act ${ }^{11}$ which created a new division in the Treasury Department to be known as the Federal Alcohol Administration. Congress eliminated from the Federal Alcohol Administration Act all provisions formerly contained in the liquor codes dealing with price maintenance, limitation of production, and allocation of

\footnotetext{
${ }_{4}^{8} 8$ STAT. 195 (1933). $\quad{ }^{2}$ Exec. Order 6474 .
}

${ }^{10}$ Schechter Bros. Poultry Corp. v. U. S., 295 U. S. 495 (1935).

${ }^{11} 49$ STAT. 977 (1935), 27 U. S. C. \$\$201 et seq. The Act is referred to several times in this paper, but will not be hereafter cited in the footnotes. 
importations. A brief description of the experiments made in the early days of Repeal in the limitation of distilled spirits production, and in the curtailment of importations, would seem in order at this point.

\section{Experiments in Limiting the Volume of Distilled Spirits Produced and Imported}

The original Code of Fair Competition for the Distilling Industry, approved by the President on November $26,1933,{ }^{12}$ provided for the issuance of distillers permits to cover only existing plants, or plants under construction at the time of Repeal, except, after hearing, on a finding that new plant capacity was necessary to meet present or potential consumptive demands. Distilling permits, containing definite limitations upon the plant facilities" which might be employed and the quantities which might be produced in a 24 -hour period, were issued promptly on and after December 5, 1933 , to proprietors of existing plants and to persons engaged in building them. Distilling plants in existence at the time of Repeal and in process of construction, covering which code permits were issued, had an authorized theoretical capacity of over 270 million gallons of whisky, gin, brandy, and rum per year. ${ }^{13}$ Nevertheless applications for permits came in large numbers from persons desiring to commence the construction of new distilleries and approximately roo such applications were denied up to September, I934, consistent with the policy of discouraging additional plant capacity. During this period considerable criticism was leveled at the Federal Alcohol Control Administration for allegedly fostering monopoly by refusing to allow new distilling enterprises to go into competition with vested interests. In March, 1935, a public hearing was conducted in Washington on a proposal to amend the distillers' code by eliminating therefrom restrictions upon the issuance of permits on a basis of existing plant capacity, and to open the way to issuing such permits to all applicants who could qualify on the basis of experience, trade connections and financial standing as potential legal producers. Following this public hearing the distillers' code was so amended on April 5, 1935, and thereafter all efforts on the part of the government to curtail or limit production were abandoned.

In announcing the adoption of the new policy the Federal Alcohol Control Administration stated:14

"these provisions had been incorporated into the Code as originally written in order to keep out of the industry in its early stages an anticipated swarm of speculators, seeking quick easy profits in the distilling business. The waste of capital investment and the demoralization of the existing industry through excessive competition, necessarily resulting from the inclusion of such unstable elements into a new industry, was largely prevented by these provisions. A year's experience now demonstrates to the prospective investor that ability and experience are as necessary in the distillery business as in other types of business, and that the opportunity for easy financing of, and large and quick returns on, distillery investments is exceedingly limited.

"Since an undue increase in the size of the industry is no longer to be expected, the original Code provisions have to some extent outlived their usefulness and it is felt that

12 Exec. Order No. 6444 -A.

${ }^{23}$ FACA Release, Apr. 29, 1934.

${ }^{14}$ FACA Release 196, Apr. 8, 1935. 
the burdens they place upon prospective industry members are no longer justified. They have operated unfairly by preventing citizens of states which have but recently become wet from entering the industry and have unduly hindered the successful small operator from enlarging his plant to take advantage of increases in his market."

The original code of the rectifying industry, approved by the President September 9, $1933,{ }^{15}$ provided that applicants for permits must prove to the satisfaction of the Administration that their products could be absorbed "by the probable market demand." As early as May, I934, the issuance of permits to rectifiers was rigidly curtailed and during I934 and early r935 scores of applications for such permits were denied because of the applicant's inability to show that his products could be absorbed by the probable market demand. Severe criticism of this policy from many quarters led to the amendment of the rectifiers' code in April, I935, ${ }^{16}$ so as to provide thereafter for the issuance of such permits independent of any showing of a market demand.

Immediately following Repeal an effort was also made, under the Agricultural Adjustment Act, ${ }^{17}$ to limit the quantities of alcoholic beverages imported into the United States and to allocate the same among the domestic importers. The marketing agreement for the alcoholic beverages importing industry ${ }^{18}$ provided in Article III, Section 2: "From time to time the Secretary of Agriculture and the Secretary of the Treasury shall jointly determine and report to the issuing authority the kinds and amounts of alcoholic beverages permitted to be imported into the United States from each foreign country."

The determinations so made were predicated in part upon the quantities of American agricultural products which representatives of foreign governments agreed to purchase in return for wine and spirit orders. During the first three months following Repeal, authorizations were issued to import I2,837,244 gallons of alcoholic beverages of all types. ${ }^{19}$ Immediately after these allotments had been made, over I,200 persons filed applications to import an additional 50 million gallons of alcoholic beverages of all types. ${ }^{20}$ However, permits for a second import period were issued to only about 700 applicants authorizing the importation of approximately eight million gallons of alcoholic beverages of all types. ${ }^{21}$ Dissatisfaction with the allotment system was early made evident, and in view of the obvious impossibility of making an equitable and completely satisfactory allocation of quotas to individual importers, the attempt to limit importations was virtually abandoned early in March, 1934. The government has never undertaken to limit or allocate the domestic production of wine or malt beverages.

\section{The Basic Permit System}

Under federal laws in existence before Prohibition and at the time of Repeal there was no means of keeping the criminal element from entering the legalized

\footnotetext{
${ }^{16}$ Exec. Order No. 6487 -B.

${ }^{10}$ Exec. Order No. 7022.

${ }^{18}$ Agreement 25 (Dec. T, I933).

${ }^{20}$ Id. 36, Feb. 9, 1934.
}

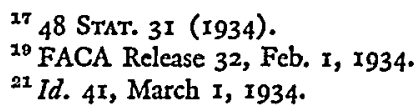


beverage liquor field. The executive branch of government, except to a limited extent in the case of distilleries, ${ }^{22}$ was powerless to prevent potential law violators and even convicted criminals from entering into the business of producing or distributing alcoholic beverages. Under this system, where violations of the revenue laws occurred upon legalized premises, or where the proprietors of registered plants committed criminal acts outside of the legalized premises, it was possible for the business to be continued upon the criminal's behalf by others while he served a jail term upon conviction, or by himself in cases where conviction resulted in the imposition of a fine.

At the very outset of Repeal a permit system was introduced into all of the alcoholic beverage industry codes, except the brewers' code, and it was made unlawful for any person to engage in these industries without a federal permit to do so. Permits were issued upon a showing of business experience, financial standing and trade connections, sufficient to satisfy the government that the business would be lawfully conducted, and were made revocable after hearing for violation of any of their terms or conditions.

Congress perpetuated this permit system when it enacted the Federal Alcohol Administration Act, and made it more effective by providing that permits should be conditioned not only upon the observance of fair trade practices but upon the observance as well of all federal laws relating to liquor. With reference to the adoption of the basic permit system, the Senate Committee on Finance in its report on the Federal Alcohol Administration bill ${ }^{23}$ said, "The revenue cannot be adequately protected, the 'tied-house' control cannot be curbed, the public cannot be protected from unscrupulous advertising, the consumer cannot be protected from deceptive labeling practices; in short, the legalized liquor traffic cannot be effectively regulated if the door is left open for highly financed gangs of criminals and racketeers to enter into the business of liquor production and distribution."

Under the Federal Alcohol Administration Act no person is entitled to a basic permit if he (or in the case of a corporation any of its officers, directors or principal stockholders) has, within five years prior to date of application, been convicted of a felony under federal or state law or has, within three years prior to date of application, been convicted of a misdemeanor under any federal liquor law. It is also provided that permits be denied to persons who by reason of business experience, financial standing or trade connections are not likely to commence operations within a reasonable period or maintain operations in conformity with federal law. No permit may be issued to authorize operations which would be in violation of the laws of the state in which they are proposed to be conducted.

All permits are conditioned upon the fair trade practice sections of the Federal Alcohol Administration Act, with the Twenty-first Amendment and laws relating to the enforcement thereof, and with all other federal laws relating to distilled spirits,

\footnotetext{
${ }^{23} 21$ STAT. 145 (I880).

${ }^{23}$ Sen. Rep. No. 1215, 74th Cong., Ist Sess. (1935).
} 
wines and malt beverages, including taxes with respect thereto. Any permit after notice and opportunity for hearing may be annulled for fraudulent procurement, revoked for two years' inactivity, suspended for a furst violation of any of its terms and conditions, and revoked for any subsequent violations of its conditions. In any case where the business covered by the permit is leased, sold or otherwise voluntarily transferred, the permit is automatically terminated, making necessary the procurement of new permits by the new proprietors.

An appeal may be taken from any order denying, suspending, revoking or annulling a basic permit by filing within sixty days after the entry of such order, a written petition in the circuit court of appeals for the circuit wherein the permittee or applicant resides or has his place of business, or in the United States Court of Appeals for the District of Columbia. The proceedings are not de novo, but upon the record filed by the administrative department. The court is empowered to affirm, modify, or set aside the order in whole or in part but the findings of the administrative department as to the facts, if supported by substantial evidence, are conclusive. In any case where a petition is filed in the circuit court of appeals the commencement of the proceedings, unless specifically ordered by the court to the contrary, operates as a stay of the order.

Only two cases have so far arisen in which appeals have been taken under this Act from orders denying or suspending permits, Atlanta Beer Distributing Co., Inc. v. Alexander ${ }^{24}$ and Arrow Distilleries, Inc. v. Alexander. ${ }^{25}$ In the Atlanta Beer case an application for permit was denied because the president and sole stockholder of the company was convicted of liquor law violations, more than three years prior to the date of application and by reason of that fact the company was not regarded as likely to maintain its operations in conformity with federal law. Petitioner contended that he was not convicted of a felony within five years of the date of his application, nor of a misdemeanor within three years, and could not therefore be denied a permit on the ground specified. The court held otherwise. An attack was made upon the constitutionality of the permit requirements of the Act but it was held not competent to make such an attack in a proceeding for a license under the Act.

In the Arrow case an appeal was taken from an order suspending the company's permit for several violations of its terms and conditions. The facts were held to support the action taken, and in passing upon the constitutional question the court said:20

"We are of the opinion that it is clearly within the power of Congress to make it unlawful for one to engage in the operations of rectifying, distilling and bottling alcoholic liquors for interstate trade without first obtaining a permit from the United States. Also we think Congress has the power to condition a permit upon compliance with the requirements of the Alcohol Administration Act, the twenty-first Amendment, and laws relating to the enforcement thereof, and to all other federal laws relating to distilled spirits, wine, and malt beverages." (italics supplied)

\footnotetext{
${ }_{24}^{24}$ F. (2d) 1 II (C. C. A. 5th, 1937).

${ }^{25}$ Iog F. (2d) 397 (C. C. A. 7 th, 1940). $\quad{ }^{20} 1 d .40$ r.
} 
Whether or not the Act is valid in so far as it purports to require permits to cover the distribution of alcoholic beverages solely intrastate, or the production of alcoholic beverages exclusively for intrastate sale, has been left undecided. Should the constitutionality of the permit system, as applied to purely intrastate transactions, be rested exclusively upon the power of Congress to regulate interstate commerce, it would be of doubtful validity. The Court points out in the Arrow decision, however, that it is not necessary that the Act as a whole rest upon a single power of Congress. According to Section 3 of the Act, ${ }^{27}$ Congress, in prescribing the permit system, was exercising its power not only to regulate interstate commerce but likewise to protect the revenue, to enforce the postal laws, and to enforce the Twenty-first Amendment. Whether the permit system as applied to wholly intrastate operations is valid because essential to revenue protection, or is an appropriate means of preventing the shipment of liquor across state lines for unlawful delivery or use in contravention of the Twenty-first Amendment, must be left to future decisions of the courts.

\section{Restrictions on Bulk Sales}

There was no federal pre-Prohibition limitation upon the movement of alcoholic beverages into wholesale and retail channels in bulk containers. Restrictions upon bulk shipments appeared for the first time in the distillers', rectifiers' and importers' codes adopted pursuant to the National Industrial Recovery Act. It was required by these codes that all distilled spirits be bottled at a distilling or rectifying plant, or in the case of imports by the foreign shipper.

The post-Repeal policy that distilled spirits destined for the consumer trade be packaged in bottles, was based primarily upon revenue considerations. Were wholesalers and retailers permitted to have bulk goods on the premises it would facilitate the use of these premises as outlets for bootleg liquor, since the refilling of bulky containers with untaxpaid liquor from bootleg sources would be a simple matter and difficult of detection.

When the N. I. R. A. codes were invalidated by the Supreme Court decision in the Schechter case ${ }^{28}$ steps were taken to secure legislation continuing these restrictions upon bulk sales. Provisions to accomplish this end incorporated in the bill to create the Federal Alcohol Administration provoked heated debate in Congress. The House originally favored relaxation of the restrictions on bulk sales, contending that the cooperage industry would be benefited thereby, that the price of whisky to the consumer would be lower, and that such action would tend to prevent monopolization of the liquor container business by bottle manufacturers. The Senate on the other hand opposed bulk distribution and insisted that all distilled spirits be packaged at the source, in containers of one gallon or less capacity, in order to insure against tax evasions, misbranding and adulteration. The House receded from its original position and as a consequence the Federal Alcohol Administration Act, as passed, prohibits sales of distilled spirits in containers of more than one gallon capacity except 
to distillers, rectifiers, bonded warehouse proprietors, wine producers, industrial alcohol plants, and state and federal agencies. It is also made unlawful for any class of persons, except those referred to, to engage in bottling operations. No proceedings have yet been instituted in the courts challenging the validity of the legislation.

Restrictions upon bulk sales have thus far been applied only to distilled spirits. No federal curtailment has ever been placed upon the use of barrels or kegs in shipping malt beverages and wines into wholesale, retail and consumer channels. A trend toward the wider distribution of these products in bottles and cans is, however, noticeable. Prior to Prohibition only $25 \%$ of the beer consumed in the United States was bottled beer. Today packaged beer sales are approximately $50 \%$ of the total.,9

\section{Regulation of Bottle Manufacturers and Bottle Sizes}

The bulk sales legislation, supplemented by a Joint Resolution of Congress, approved June I8, 1934, "To protect the revenue by regulation of the traffic in containers of distilled spirits"30 has revolutionized the pre-Prohibition system of liquor distribution. The supervised producer superseded the wholesale and retail dealer as a bottler of spirits. The unlabeled flask in which a large percentage of the pre-Prohibition whiskey was dispensed from retail saloons and taverns has disappeared from the legitimate market. The distiller has become a national distributor of bottled goods. He now bids directly for the consumer trade, as well as the trade of the wholesaler and retailer, and competition between producers, evidenced by advertising on a much larger scale than ever before, is based upon the brand or trade name on the labeled bottle, rather than upon the contents of the barrel as formerly.

With this change in merchandising policy has come a new type of federal regulation. No control was exercised by the Federal Government prior to Repeal over the sizes of liquor bottles, or with respect to their manufacture or use. Rigid restrictions are now imposed by the Alcohol Tax Unit upon the manufacture, sale, resale, possession, use and reuse of liquor bottles. ${ }^{31}$ No person is authorized to manufacture liquor bottles unless he has procured a permit to do so from the Alcohol Tax Unit of the Bureau of Internal Revenue. Premises in which liquor bottles are manufactured or stored must be of sound construction and adequately protected to insure against the diversion of the bottles to unauthorized sources. Bottle manufacturers operating under permit are precluded from selling or disposing of liquor bottles except to authorized bottlers of distilled spirits. The importation of empty liquor bottles, with certain exceptions, is prohibited and the possession of used liquor bottles by any person other than the one who emptied the contents of the bottle is prohibited. Bottles intended for use in packaging distilled spirits must have blown therein symbols identifying the bottle manufacturer, the distilled spirits bottler, and also the phrase "Federal law forbids sale or reuse of this bottle."

Under the Federal Alcohol Administration Act regulations have also been pre-

${ }^{29}$ See Persons, Beer and Brewing in America (Rev. ed. i940) 18.

${ }^{30} 48$ StAT. I020 (1934); INT. REv. Code $\$ 2871$ (1939) (hereafter cited I. R. C.).

${ }^{81}$ A. T. U., Reg. 13 . 
scribed $^{32}$ standardizing the sizes of bottles in which liquor may be packaged, and prohibiting the marketing of liquor in containers other than those of the sizes prescribed. Under these regulations the standards of fill for all distilled spirits, whether domestically manufactured, domestically bottled, or imported, are $x$ gallon, $1 / 2$ gallon, I quart, $4 / 5$ quart, I pint, $1 / 2$ pint, $1 / 8$ pint, and $1 / 10$ pint. In addition to these sizes a $1 / 16$ pint container is authorized for use in packaging brandy and a $4 / 5$ pint size container is authorized for brandy and rum, Scotch and Irish whisky, and Scotch type and Irish type whisky.

\section{Strip Stamps Denoting Tax Payment}

The Liquor Taxing Act of $1934,{ }^{33}$ approved January II, 1934, introduced for the first time a federal requirement that all distilled spirits bottles have affixed thereto a stamp denoting the quantity in the container and evidencing the payment of all internal revenue taxes due thereon. Prior to Prohibition the only bottled distilled spirits to which federal strip stamps were affixed were spirits bottled under the Bottling in Bond Act of March 3, $1897^{34}$ Under this act it was provided that spirits of the same kind, produced at the same distillery, by the same distiller, in the same distilling season, and aged four years or more, might be mingled together and bottled in bond, and that every bottle should have affixed thereto, by passing over the mouth of the same, an adhesive engraved strip stamp to be prescribed by the Commissioner of Internal Revenue. The strip stamps prescribed for use under the Bottling in Bond Act, and in use since the act was passed in 1897 , have been intended only to denote that the product is an authentic distillery-bottled product meeting the specifications of the Bottling in Bond Act, and was never intended as a means of distinguishing between bootleg liquor and liquor which had been taxpaid.

The new policy adopted in the Liquor Taxing Act of 1934, which requires the affixing of strip stamps denoting taxpayment to all distilled spirits containers, has as its objective the suppression of bootleg operations, in that liquor in bottles which do not have affixed thereto genuine federal strip stamps over the mouth can be definitely identified as untaxpaid products introduced into the market by illicit operators.

Strip stamps under this act and under the Bottling in Bond Act are issued by the Commissioner of Internal Revenue to each collector of internal revenue in the number necessary to meet the requirements of his district, and are sold by the collectors under rigid regulations to persons entitled to bottle or import distilled spirits. The stamps sell for one cent each, except for containers of less than one-half pint, in which case the price of the stamp is $1 / 4$ of one cent. The revenue derived from the sale of stamps is, of course, in addition to the internal revenue taxes collected on the spirits. It is specifically required by law that any person emptying a liquor container immediately destroy the stamp thereon. All distilled spirits found in unstamped containers are forfeited to the United States. Any person violating the provisions of the

\footnotetext{
${ }^{32}$ F. A. A., Reg. 5.
}

${ }^{33}$ I. R. C. $\$ 2803$.

${ }^{34} 29$ STAT. 626 (1897). 
act, or who counterfeits any stamp, or has in his possession any counterfeited stamp, or plate or dye used in its manufacture, or has in his possession any paper in imitation of the paper used in the manufacture of such stamps, or who reuses any stamp, upon conviction may be punished by a fine not to exceed $\$ 1,000$, or by imprisonment at hard labor not exceeding five years, or both.

\section{Control of Sources of Supply for Raw Materials}

If illicit distillery operators were unable to procure raw materials from which alcohol could be distilled there would be no bootleg liquor problem. Congress, since Repeal, in recognition of this fact, has seen fit to give the Commissioner of Internal Revenue some control over the sources of supply for distilling materials. Joint Resolution 373, approved June 18,1934 , "To protect the revenue by requiring information concerning the disposition of substances used in the manufacture of distilled spirits" provides:

"Every person disposing of any substance of the character used in the manufacture of distilled spirits shall, when required by the Commissioner, render a correct return in such form and manner as the Commissioner, with the approval of the Secretary of the Treasury, may by rules and regulations prescribe, showing the names and addresses of the persons to whom such disposition was made, with such details, as to the quantity so disposed of or other information which the Commissioner may require as to such disposition, as will enable the Commissioner to determine whether all taxes due with respect to any distilled spirits manufactured from such substances have been paid."

In pursuance of this authority regulations have been prescribed ${ }^{30}$ to facilitate the tracing of substances such as molasses, sugar, yeast, cider, malt, oak chips, corn meal, cracked corn and bran to illicit distilling plants. It is provided in these regulations that every person in the United States who consigns, sells or otherwise disposes of these substances (other than such small dealers as are specifically exempted) shall keep such books, records, invoices and bills of lading relating to each consignment, as will show the date of sale, the quantity and kind of material sold, the names and addresses of the purchaser and the consignee, the date and method of shipment or delivery, the registration number of the truck in which delivered, the driver's name and address, the name and address of the person to whom delivered and the exact date of delivery. This information must be supplied, under penalty, in the form of a report when called for in writing by the Commissioner of Internal Revenue or his authorized representative. Similar regulations have been prescribed ${ }^{37}$ requiring records and reports upon shipments of denatured alcohol, denatured rum, ethyl acetate, and all liquid substances or preparations containing more than 25 percent by volume of denatured alcohol or denatured rum.

The constitutionality of the raw materials resolution was early challenged in the courts, and its validity has been upheld in several cases in the circuit courts of appeal,

${ }^{35}$ I. R. C. $\$ 28 \mathrm{II}$.

${ }^{30}$ A. T. U., Reg. I7.

${ }^{37}$ Id., Reg. 92. 
in three of which certiorari was denied by the Supreme Court..8 ${ }^{38}$ the Goldsmith case the Circuit Court of Appeals for the Second Circuit stated:39

"One who disposed of the substances covered by the resolution, of which sugar was certainly one, was liable under the law to make such reports designed to provide the check which the Commissioner might find he needed in determining whether all of the taxes mentioned were paid. Congress could provide him with the means for obtaining such information in whatever detail might be necessary and that it preferred to let the Commissioner decide as to the need in the actual administration of the law rather than to require all dealers in such substances make reports, often perhaps wholly unnecessary and unwanted, curtailed the rights of no one. One who disposed of such substances might well insist that he be required to furnish only such information as would enable the Commissioner to make his determination regarding the payment of taxes but he could have no rights infringed because the Commissioner did not require all, or others, who also disposed of such substances to give information too. We think this delegation of power was properly limited to administrative details within United States $v$. Grimaud, supra, and that is so regardless of the fact that the regulations there involved only dealt with public lands. These regulations deal with the public revenue and, though it may be that they more closely affect private rights we believe the resolution is so limited that action within its scope was lawful."

\section{Aicohol Tax Unit and Its Functions}

Prior to 1934 the internal revenue laws relating to liquor were administered by the Bureau of Industrial Alcohol of the Treasury Department. This Bureau was abolished by Executive Order, ${ }^{40}$ and in May, I934, a new Unit of the Internal Revenue Bureau was created ${ }^{41}$ known as the Alcohol Tax Unit, headed by a Deputy Commissioner of Internal Revenue. The Alcohol Tax Unit, prior to July I, I940, upon which date it took over the functions of the Federal Alcohol Administration, was charged with the administration, under the direction of the Commissioner of Internal Revenue, of the internal revenue laws concerning the following subjects:

(I) the establishment, construction, operation, custody, and supervision of distilleries, industrial-alcohol plants, bonded warehouses, denaturing plants, wineries, bonded-wine storerooms, breweries, rectifying houses, dealcoholizing plants, cereal beverage plants, and other places at which such spirits, liquors, or liquids are produced or stored;

(2) the determination, assertion, and assessment of all internal revenue taxes and penalties pertaining to distilled spirits, alcohol, wines, fermented liquors, cereal beverages, denatured alcohol, denatured rum, and articles containing denatured alcohol or denatured rum, and other such liquors and liquids, and the compromise thereof (all moneys are received and accounted for by the collectors of internal revenue);

(3) the investigation, prevention, and detection of violations of the laws pertaining to the products referred to, and any regulations issued thereunder, and the apprehension of offenders against such laws;

${ }^{38}$ U. S. v. Goldsmith, 9I F. (2d) 983 (C. C. A. 2d, 1937), cert. denied, 302 U. S. 718 (1937); Nick Dano v. U. S., 91 F. (2d) 1012 (C. C. A. 3d, 1937); DiSanto v. U. S., 93 F. (2d) 948 (C. C. A. 6th, r937), cert. denied, 303 U. S. 662 (1938); U. S. v. Tishman, 99 F. (2d) 95I (C. C. A. 7th, x938), cert. denied, 306 U. S. 636 (1939).

${ }^{40}$ Exec. Order 6639, Mar. Io, 1934.

${ }^{30} 9$ I F. (2d) at $985-986$.

11 U. S. Treas. Dec. $4432,4662$. 
(4) the detention and seizure, for violation of internal revenue liquor laws, of property, whether real or personal, except seizures under distraint warrant, and the custody, control, sale, and disposition of property so seized;

(5) the regulation of the size, branding, marking, sale, resale, possession, use, and reuse of containers used for the sale of distilled spirits at retail, and the issuance, suspension and revocation of permits for the manufacture, storage, procurement and transportation of such containers.

\section{Abolition of Federal Alcohol Administration}

Up until July, I940, the responsibility for regulating the alcoholic beverage industries was divided between two agencies of the government, each of which was a part of the Treasury Department. The Alcohol Tax Unit supervised all branches of the industry for tax collection purposes, and was devoted to apprehending and punishing liquor tax evaders. The Federal Alcohol Administration, created as a Division of the Treasury Department by the Federal Alcohol Administration Act on August 29, I935, regulated the trade practices of the industry and administered the basic permit system established by that act. It was the duty of this agency to enforce those provisions of the Federal Alcohol Administration Act which prohibited exclusive outlets, tied-houses, commercial bribery and consignment or conditional sales; to promulgate and enforce regulations relating to labeling and advertising of alcoholic beverages; to enforce those provisions of the act restricting the sale of distilled spirits in bulk; and to prevent the combination through interlocking directorates of business enterprises engaged in production, importation or distribution, where such combinations tended to burden interstate commerce. The fact that the basic permits issued under the Federal Alcohol Administration Act were not conditioned solely upon the observance of fair trade practices, or upon compliance with regulations issued by the Federal Alcohol Administration, resulted in divisions of responsibility and overlapping of functions.

One of the purposes of the Federal Alcohol Administration Act, as stated in its title, is to "further protect the revenue derived from distilled spirits, wine and malt beverages," and the basic permits issued to the industry under that act have been conditioned, among other things, upon compliance with the Twenty-first Amendment and laws relating to the enforcement thereof, "and with all other Federal laws relating to distilled spirits, wine and malt beverages, including taxes with respect thereto." In cases where permit holders violated internal revenue laws, and were apprehended in such violations by the Alcohol Tax Unit, proceedings against the basic permits of the violators were instituted by the Federal Alcohol Administration. To that extent the responsibility for enforcing even the internal revenue laws relating to liquor became a divided responsibility. The same overlapping of functions was evident in other phases of liquor control, such as labeling. The Alcohol Tax Unit, for internal revenue purposes, controlled the labeling of products intended for intrastate distribution while the Federal Alcohol Administration regulated the interstate aspects of the question. With respect to the labeling of merchandise for interstate sale, internal 
revenue officers on duty at bottling plants had the responsibility of seeing to it that the proper labels were affixed, and were required to prevent the removal of merchandise from the plant unless the bottler possessed the necessary certificates of label approval issued by the Federal Alcohol Administration.

This situation led to the abolition of the Federal Alcohol Administration by Reorganization Plan No. 3, transmitted to Congress by the President on April 2, 1940, pursuant to the Reorganization Act of $1939 .{ }^{42}$ Section 2 of this plan provides:

"Sec. 2. Federal Alcohol Administration.-The Federal Alcohol Administration, the offices of the members thereof, and the office of the Administrator are abolished, and their functions shall be administered under the direction and supervision of the Secretary of the Treasury through the Bureau of Internal Revenue in the Department of the Treasury."

In transmitting this plan to Congress the President stated: $:^{43}$

"I propose, therefore, that the functions of the Federal Alcohol Administration be correlated with the activities of the Bureau of Internal Revenue, particularly its Alcohol Tax Unit. The Bureau is already performing a large part of the field enforcement work of the Administration and could readily take over complete responsibility for its work. The Bureau is daily making, for other purposes, a majority of the contacts with units of the liquor industry which the Federal Alcohol Administration should but cannot make without the establishment of a large and duplicating field force. Under the provisions of this plan, it will be possible more effectively to utilize the far-fung organization of the Treasury Department, including its many laboratories, in discharging the functions of the Federal Alcohol Administration. Thus, I find the proposed consolidation will remedy deficiencies in organization structure as well as afford a more effective service at materially reduced costs."

The powers vested in the Secretary of the Treasury by this legislation were delegated by him on June 12, 1940, to the Deputy Commissioner of Internal Revenue in charge of the Alcohol Tax Unit. Almost immediately the basic permit system theretofore centrally administered out of Washington, was decentralized into the fifteen Alcoholic Tax Unit field offices scattered throughout the country, and the power and duty to issue, amend, deny, revoke, suspend and annul basic permits under the supervision and direction of the Deputy Commissioner of Internal Revenue in charge of the Alcohol Tax Unit was delegated to the district supervisors in charge of the field offices. ${ }^{44}$

The duty of regulating the alcoholic beverage industries has now become vested in one agency of the government, the Alcohol Tax Unit of the Internal Revenue Bureau, except for such functions as may be exercised by the Bureau of Customs of the Treasury Department in connection with the release of merchandise from customs custody for domestic consumption and the suppression of smuggling operations. Although the Federal Trade Commission has jurisdiction over false advertising by virtue of the recent Wheeler-Lea amendment to the Federal Trade Commission

${ }^{12} 53$ Stat. 56r (1940). $\quad{ }^{3}$ Ibid.

«U. S. Treas. Dec. 4975 (June I2, I940), 4982 (July Ir, I940). 
Act, ${ }^{45}$ and the Food and Drug Administration has jurisdiction over labeling under the terms of the new Food, Drug and Cosmetic Act ${ }^{46}$ these agencies have seldom undertaken to exercise jurisdiction in matters of labeling, advertising or trade practices which are specifically covered by provisions of the Federal Alcohol Administration Act.

\section{Decentralized Control}

The Alcohol Tax Unit regulates the alcoholic beverage industry under a decentralized control system, with the Washington office devoting itself primarily to promulgating regulations for the control of the industry, and supervising and instructing field officers in the performance of their duties, to insure uniformity and efficiency of office and investigative procedure. Even with the increased functions assumed since the abolition of the Federal Alcohol Administration, there are few matters in which original action is taken by Washington. These include: (I) the examination and approval of blue prints and plans showing construction or changes in construction of plants producing and processing distilled spirits, and the examination and approval of indemnity bonds, and bonds given by the proprietors of such plants to insure payment of internal revenue taxes due upon the alcoholic products produced; (2) giving recommendations to the Department of Justice, upon applications for pardon or parole made by prisoners committed for liquor violations; (3) receiving copies of all reports from field offices disclosing violations of internal revenue laws, and computing therefrom and assessing the internal revenue taxes and penalties imposed by law, such taxes and penalties after assessment being listed for collection by the various collectors of internal revenue; (4) acting upon claims for abatement and refund of liquor taxes alleged to have been erroneously assessed or collected; (5) acting upon offers in compromise of civil or criminal liability incurred for violation of internal revenue liquor laws; (6) acting upon petitions for mitigation or remission of forfeitures of motor vehicles and other property seized and forfeited under internal revenue liquor laws; (7) acting upon applications for certificates of label approval filed under the Federal Alcohol Administration Act; (8) examining for compliance with law and regulations advertising copy appearing in daily newspapers and national magazines, and informally passing upon proposed liquor advertising copy submitted by the industry for criticism in advance of publication; (9) acting upon interlocking directorate applications in cases where the taking of office in more than one company engaged in business as a distiller, rectifier or blender of distilled spirits is contingent upon the receipt of the Deputy Commissioner's approval thereto under the Federal Alcohol Administration Act.

The total personnel of the Washington office of the Alcohol Tax Unit is only I98 out of a total personnel of approximately 4,400 assigned to Unit activities. There are I5 field offices of the Unit scattered throughout the United States, each such office being in charge of a district supervisor, in whom is vested the direct and primary

$$
{ }^{45}{ }_{52} \text { STAT. I14, } 15 \text { U. S. C. } \$ 52 \text { (1938). } \quad{ }_{52}^{40} \text { STAT. 1046, 2I U. S. C. } \$ 341 \text { (1938). }
$$


responsibility in his district of: (I) investigating, preventing and detecting violations of federal liquor laws, apprehending offenders against such laws, and reporting violations to the United States Attorney for prosecution; (2) detaining and seizing alcoholic beverages and other types of property, real and personal, made subject to forfeiture for violations of internal revenue liquor laws and disposing of the property so seized; (3) supervising operations of all lawfully established distilleries, industrial alcohol plants, bonded warehouses, denaturing plants, wineries, bonded wine storerooms, breweries, rectifying houses, dealcoholizing plants, cereal beverage plants, and other places at which such spirits or liquids are produced or stored; (4) passing upon applications for permits under the internal revenue laws to manufacture industrial alcohol, procure it taxfree, denature it, and deal in, use or transport specially denatured alcohol and alcohol taxfree, and citing such permits for revocation, holding hearings thereon, and revoking the same for violations of their terms and conditions; (5) issuing, suspending and revoking permits for the manufacture, storage, procurement and transportation of bottles designed or intended for use for the sale at retail of distilled spirits; and (6) acting upon all applications for permits filed by importers and wholesalers of distilled spirits, wine and malt beverages, producers, blenders and rectifiers of wine, and distillers, rectifiers, blenders and bottlers of distilled spirits for beverage use, under the Federal Alcohol Administration Act, and suspending, revoking and annulling such permits after hearing for violation of their terms and conditions.

\section{Scope of Supervision Exercised over Industry}

Under the internal revenue laws the tax attaches to alcohol as soon as this substance is in existence as such, whether it be subsequently separated as pure or impure spirit, or transferred into any other substance, either in the process of original production or by any subsequent process. ${ }^{47}$ In regulating and supervising the liquor industry, however, the government does not wait until alcohol is present in a fermenting mash before exerting its regulatory powers, nor does it cease its vigilance over the industry at the moment of tax payment.

(a) Construction and equipment of plants-Rigid specifications are imposed with respect to the construction and equipment of all plants in which distilled spirits, wines or malt beverages are produced, stored, bottled or rectified. The regulations governing the construction and equipment of distilling plants, although more rigid than those governing the construction and equipment of breweries and wineries, because of the higher rate of tax applicable to the product, are typical. A distilling plant may not be located in any dwelling house or on board any vessel or boat, or in any building where beer, vinegar or ether is manufactured, or where sugars or syrups are refined, or where liquors of any description are retailed, or within six hundred feet in a direct line from a vinegar factory using the vaporizing process. ${ }^{48}$ The distillery buildings must be securely constructed of brick, stone, wood, concrete

$$
\text { 47. R. C. } \$ 2800 \text { (a). }
$$$$
{ }^{\ll 8} \text { I. R. C. } \$ 2819 .
$$ 
or other substantial material and must be completely separated by unbroken partitions of substantial construction from contiguous buildings. Specifications are laid down with respect to the construction of the foundations, floors, walls, roofs, and doors, and requirements are imposed for the protection of windows, skylights and ventilators with iron bars and metal grates, where so located as to provide any opportunity for access to the premises. Portions of the premises intended for storing grain, storing empty containers, fermenting the mash, distilling the spirits, and storing the finished product must be separated by partitions. The distiller is required to provide and maintain on the premises, for the exclusive use of government officers, a furnished room for the preparation and safe keeping of government records. No fence or wall of a height greater than five feet may be erected around distillery premises without special permission, and keys to the gates or doors of any fence or wall surrounding a distillery must be furnished to government officers.

The distillery once erected in accordance with the rigid specifications imposed as to construction, must be equipped to meet the requirements of regulations equally as rigorous. Laboratory apparatus suitable for the testing of samples must be provided, as well as scales for weighing packages of distilled spirits and grains and other materials entering into their manufacture. Weighing tanks must be constructed to specifications, and secured with government locks. To insure accuracy of measurement there must be provided upon the premises testing weights conforming to the requirements of the National Bureau of Standards. The door of each still furnace or boiler must be so constructed that it may be closed or locked with a government lock, unless the stills are heated with steam, in which case the pipe lines used to convey the steam to the stills must be provided with valves equipped for locking with government locks at the point where they enter the still. Chutes or pipe lines used for conveying distilling material into the premises must be similarly equipped, as well as the inlets and outlets to all stills. Specifications are laid down for construction of fermenters, stills, tanks, rectifying equipment, receiving cisterns, and in the case of pipe lines, these specifications go to the detail of prescribing the color which pipes shall be painted. Pipe lines conveying spirits, vapors, mash, fermenting materials, residue, water, steam, air and carbon dioxide are all required to be of different colors.

Accurate plats and plans of the distillery premises, apparatus and equipment, drawn to scale, must be filed with the district supervisor, showing the outer boundaries of the distillery premises by courses and distances. The plans must include a floor plan of each floor of the building, showing the dimensions of the floors and rooms, location and dimensions of all doors, windows and other openings, and the location of all pipe lines, government locks, apparatus and equipment. Similar plats and plans are also required to be filed, and examined for compliance with internal revenue structural requirements, in the case of rectifying plants, bonded warehouses, taxpaid bottling premises, breweries, and wineries.

(b) Bonds-Whenever any distiller defrauds or attempts to defraud the United States of tax, the distillery and distilling apparatus used by him, and all distilled spirits 
and raw materials on the premises, are forfeited. ${ }^{49}$ The tax is a first lien on the spirits distilled, the distillery itself, and the real estate upon which the distillery is located. The lien attaches at the time the spirits come into existence as such and remains attached until the tax is paid. ${ }^{50}$ Where the distiller is not the owner in fee, unencumbered, of the land on which the distillery is located, or is not the owner of the equipment, unencumbered, he must file with the district supervisor the written consent of the owner and of any mortgagee, judgment creditor, conditional sales vendor, or other lienor or lessor, that the property may be used for distilling spirits, and expressly stipulating that the lien of the United States for taxes and penalties shall have priority over any right, title or interest of the person giving the consent, and that in case of forfeiture of the distillery premises or property, or any part of it, the title shall vest in the United States, discharged from any such right, title or interest. Where the consent of the owner cannot be obtained, provision is made for the filing by the distiller of an indemnity bond in lieu of consent, the penal sum of the bond being equal to the appraised value of the land, buildings and apparatus used by the distillery. ${ }^{51}$

In addition to the indemnity bonds given by the distiller, in cases where the owner of the property or equipment will not stipulate that the lien of the United States for taxes and penalties shall have priority, the distiller must give a separate bond with surety or collateral security in the maximum amount of $\$ 100,000$, but not less than the amount of the internal revenue tax upon the maximum quantity of the distilled spirits that can be produced in the plant in a fifteen-day period. ${ }^{52}$ This bond is conditioned on faithful compliance with all revenue laws, including those provisions relating to the payment of tax, and upon the payment of all penalties incurred, or fines imposed for the violation of such laws. Similar bonds varying in the amount of penal sum, depending upon the class and scope of operations conducted, are also required to be filed and approved as a condition precedent to the operation of any brewery, winery, bonded warehouse or rectifying plant.

No person may commence business as a distiller, rectifier, brewer or wine maker until the required bonds have been filed and approved by the Commission of Internal Revenue, or his duly authorized representative. ${ }^{53}$ The Commissioner is authorized to disapprove any bond if the individual, partnership, corporation or association giving the same, or owning, controlling or actively participating in the management of the business, has been previously convicted in a court of competent jurisdiction (I) of any fraudulent non-compliance with any provision of any law of the United States relating to internal revenue or customs taxation of alcoholic beverages, or if the offense is compromised, or (2) of any felony under any state or federal law prohibiting manufacture, sale, importation or transportation of alcoholic beverages. ${ }^{54}$ In the case of distilleries, provision is also made for the disapproval of the bond in

\footnotetext{
${ }^{40}$ I. R. C. $\$ 2806(f)$.

${ }^{50}$ I. R. C. $\$ 2800(e)$.

${ }^{52}$ These provisions of law and regulations are not applicable to brewers, wineries or rectifying plants.

${ }^{52}$ I. R. C. $\$ 28 \mathrm{I}_{4}$.

Es I. R. C. $\$ 2815(c)$.

${ }^{54}$ I. R. C. $\$ 28 \times 5$ (d).
} 
cases where the situation of the distillery, viz., its physical location and construction, is such as would enable the distiller to defraud the United States. ${ }^{55}$ All changes and alterations in plant construction or equipment must also be approved by the Alcohol Tax Unit.

(c) Permits-The requirements of internal revenue laws and regulations with respect to plant construction and the posting of bonds having been complied with, application must be filed with the district supervisor for a basic permit under the Federal Alcohol Administration Act. All distillers, rectifiers, blenders and bottlers of beverage spirits, all producers, blenders and rectifiers of wine, and all importers and wholesalers of spirits, wine and beer are required to obtain such permits. Brewers are exempt from the permit requirements of this act.50 Although convictions for felonies or misdemeanors within the period specified in the statute furnish an absolute bar to the issuance of a permit, there is nevertheless vested in the district supervisors the discretion to disapprove applications from persons who have not been convicted but who, because of business experience, financial standing, or trade connections, are not likely to operate in conformity with federal law. However, no application for permit may be disapproved until the applicant has been afforded due notice and opportunity for hearing on the application.

(d) Production, storage and tax payment-The degree of physical supervision by the Alcohol Tax Unit over plant operations varies according to the type of operations conducted. Thus, in the case of wineries, where the rate of federal tax on the product is low, grapes and other wine producing materials may be fermented into wine and the wine may be barreled, or bottled, and shipped with practically no direct government supervision over operations. ${ }^{57}$ The wine producer is required to keep records showing the nature and amounts of materials received in the plant for use in producing wine, and the quantity of wine manufactured therefrom, and reports of operations must be made on prescribed forms to the district supervisor periodically. The supervision over winery operations consists in the main of periodical inspections of the winery, examination of inventory of stock on hand, checking of raw materials received into the plant as against the quantities of wine produced, the examination of records showing the amount of wine removed from the plant, and the comparison thereof with records showing the amount of taxes paid. The tax upon wine is paid at the time of its removal for consumption or sale, the fact of tax payment being evidenced by internal revenue tax stamps of appropriate denominations affixed to the cask, barrel or keg in which the wine is contained. In the case of bottled wine, no

${ }^{55}$ I. R. C. $\$ 28 \mathrm{r}_{4}(\mathrm{a})(\mathrm{r})$.

${ }^{80}$ The provisions of the Federal Alcohol Administration Act, relating to the issuance, suspension, revocation and annulment of permits are discussed supra pp. $574 \mathrm{et} \mathrm{seq.}$

${ }^{57}$ The present tax rates on alcoholic beverages are: distilled spirits generally $\$ 3.00$ a proof gallon and brandy $\$ 2.75$; beer $\$ 6.00$ per barrel of $3 x$ gallons; wines less than $x 4 \%$ alcohol, 6 cents a gallon, wines from 14 to $21 \%$, I 8 cents per gallon, wines from 21 to $24 \%, 30$ cents a gallon, champagne 3 cents a half pint, artificially carbonated wine, and cordials and liqueurs containing wine, one and a half cents a half pint. I. R. C. $\$ \$ 2800,3030,3150$ as recently amended by the Revenue Act of 1940 , Pub. L. No. 565, 76 th Cong., 3d Sess. (June 25, 1940). 
stamp evidencing tax payment is required to be placed upon the immediate container, but a stamp of proper denomination must be affixed to all cases in which the individual bottles are packed.

In the case of brewers, the physical supervision over operations is more extensive, due in part to the higher rate of tax imposed upon beer and to the additional fact that brewers may produce, in addition to beer, untaxed products such as cereal beverages, malt syrups, and yeast. Complete records of all operations must be maintained and detailed reports of operations made periodically to the district supervisor. Stamps of various denominations for the tax payment of beer are available in the offices of the various collectors of internal revenue and are supplied, upon requisition, only to brewers. Prior to affixing the stamp to the barrel or keg it must have perforated therein the name of the brewer, and the stamp itself must be firmly affixed over the spigot hole of the barrel in such manner that it will be destroyed at the time of tapping, when the faucet is driven through the spigot hole. No beer may be removed from the place where produced, for domestic consumption, until the tax thereon has been paid, unless a special permit has been obtained authorizing the removal of the beer to a warehouse for temporary storage before tax payment. In breweries where cereal beverages, upon which no federal taxes are due, are produced, the removal thereof for bottling is under the immediate supervision of a government inspector, as is also beer withdrawn for export free of tax. While the Government does not maintain inspectors on duty constantly at breweries, for the purpose of supervising operations and insuring the payment of tax upon the beer removed, meters are installed in all brewery bottling houses, and the quantity of beer which runs from the brewery into the bottling house by pipe line is registered upon the meter as it goes into the bottling tank. Meters are also installed upon all racking machines in breweries, which register the quantity of beer going into barrels or kegs. These meters are regularly read by government inspectors assigned for that purpose, and checked against brewery production and inventory records to insure full payment of taxes due. In the case of bottled beer, no federal stamp denoting tax payment is affixed either to the bottle or to the case or carton in which the bottles are packed. The tax upon bottled beer is paid through the cancellation, by the brewer, of tax stamps in the proper denominations and amounts and the surrender of such cancelled stamps to the government inspector at the time he reads the meter and calculates the amount due.

In contrast with breweries and wineries the Government maintains constant physical supervision over all distillery operations, with certain exceptions applicable to the operations of fruit distilleries. One or more government officers, known as storekeeper-gaugers, must be on duty at each distillery before the distiller can commence operations. In some cases where operations are extensive, as many as twenty storekeeper-gaugers may be constantly on duty. Regulations governing the operation of distilleries ${ }^{58}$ provide that the storekeeper-gauger will have charge of the distillery

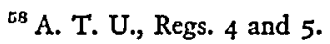


to which he is assigned, under the direction of the district supervisor. In the course of his daily duties he is required to observe the character and condition of all connections, pipes, tanks or vessels used in conveying spirits in the course of distillation, to see that they are continuous and closed as required.

Distillers must weigh or measure all material received on the distillery premises, intended for use in the production of distilled spirits, and furnish signed reports thereof to the storekeeper-gauger on duty. Such materials must be stored in a room specially provided for that purpose, under a lock to which the storekeeper-gauger holds the key. Materials may not be removed for distillation except when the storekeeper-gauger is present. From time to time the storekeeper-gauger must personally verify the accuracy of the distiller's determination of the weight or quantity of materials received and used, and must determine the number of gallons of mash in each fermenter at the time of fill, and test the alcoholic content of the mash before distillation. No mashing or distilling is permitted in the absence of the storekeepergauger from the premises. The process of distillation employed must be such that the spirits will pass through continuous closed stills, pipes and vessels from the time the vapor rises in the first still until the finished spirits are deposited in the cistern room, in locked receiving cisterns provided for that purpose. The receiving cisterns and the cistern room are under the lock and seal of the storekeeper-gauger, and the doors and other openings of the cistern room are locked at all times with government locks, except when spirits are being drawn off in the presence of the storekeepergauger. No person is permitted in the cistern room except when a government officer is present, and the keys to the government locks may not be entrusted at any time to the distiller or any person in his employ.

Although provision is made for the tax payment and immediate removal of spirits from the cistern room, in actual practice spirits such as whisky and rum are usually drawn off into barrels and deposited in a bonded warehouse for aging. No spirits can be withdrawn from the cistern room in containers of less than Io gallons capacity, and in the case of all spirits withdrawn from cisterns the storekeeper-gauger is required to personally supervise the filling of the packages, and the marking and branding thereof prior to removal into the bonded warehouse. All barrels are required to be serially numbered and also to bear markings indicating the gross weight, tare, net weight, content in gallons, and alcoholic proof of the product. The accuracy of all markings must be verified by the government officer on duty.

All internal revenue bonded warehouses, into which distilled spirits are removed for deposit pending the payment of the tax, are in charge of a storekeeper-gauger and all such warehouses, as provided by law, are in the joint custody of the storekeeper-gauger and the proprietor. ${ }^{59}$ The outside doors of the warehouse must be kept locked at all times with government locks except when spirits are being entered into or removed from the warehouse, or where it is necessary for the proprietor to have access to the warehouse for the purpose of repairing cooperage or other legitimate purposes. Distilled

${ }^{69}$ I. R. C. $\$ \$ 2872,2873$. 
spirits entered after July 26 , I928, for deposit in an internal revenue bonded warehouse may not remain stored therein more than eight years, at the end of which time the taxes due thereon must be paid and the spirits removed. ${ }^{60}$ During the period of storage in bond losses occur through leakage and evaporation, and allowances are made for these losses within certain limitations prescribed by Congress, based upon the period of time during which the spirits have remained in the bonded warehouse. ${ }^{61}$ At the time of removal from bond the content of each barrel is ascertained by the storekeeper-gauger, loss allowances calculated, and stamps evidencing tax payment, in the proper denomination and amount, cancelled and affixed to the barrel under the storekeeper-gauger's supervision.

(e) Bottling-In view of the fact that distilled spirits are not permitted to be distributed in wholesale, retail or consumer channels, for beverage use, in containers of more than I gallon capacity, distilled spirits removed from bond in barrels are transferred to the premises of rectifiers or other authorized bottling plants. ${ }^{62}$ In the rectifying plant spirits may be bottled in the same condition in which they are received, in which event no additional tax is due the government, or they may be blended together, mixed with neutral spirits, colored, converted into other products such as cordials, liqueurs, cocktails and the like, or otherwise treated in such manner as to incur liability for an additional federal tax imposed upon rectified spirits. ${ }^{63}$ Whether the distilled spirits are rectified before bottling, or bottled without rectification, all distilled spirits bottling operations are closely supervised by Alcohol Tax Unit representatives. Storekeeper-gaugers are assigned to duty at all bottling plants for the purpose of supervising bottling operations. They are required to see to it that only authorized liquor bottles are used, ${ }^{64}$ that strip stamps denoting tax payment are affixed over the mouth of each bottle, ${ }^{65}$ that the labels used are in conformity with federal requirements, and that the cases into which the bottles are packed have placed thereon the prescribed markings. All cases bear serial numbers and other data which enable the tracing of the origin of the product from the retail store back to the premises of the bottler. The bottler in turn maintains records of serial numbers of cases and barrels in such detail as to enable the tracing of the contents of individual cases of unrectified products back to the distillery in which produced.

(f) Merchandising-Wholesale and retail dealers in alcoholic beverages are required to pay occupational taxes to the Federal Government annually, varying in amount according to the type of business engaged in and the types of alcoholic beverages sold. ${ }^{60}$ Wholesalers must keep daily records of all distilled spirits received and disposed of, showing the names and addresses of the persons from whom received and to whom sold, as well as the serial numbers of the packages. Transcripts and summaries of such records are filed monthly with the district supervisors. Retailers of liquor are not required to file any report of their operations with the Federal

\footnotetext{
${ }^{00}$ I. R. C. $\$ 2900$.

D1. R. C. $\$ 290$ r.

${ }^{62}$ Supra p. 577 .

${ }^{03}$ The rectification tax is 30 cents per proof gallon under $\$ 2800(a)(5)$ of the I. R. C.

e. Suspra p. 578 .

${ }^{\text {os Supra p. } 579 .}$

${ }^{68}$ I. R. C. $\$ 3250$.
} 
Government, nor maintain records of the names of their customers, but there must be kept available for examination on retailers' premises records showing the quantities of alcoholic beverages received, the date of receipt, and the name of the vendor. ${ }^{07}$ Government supervision of wholesalers' and retailers' operations extends only to the examination of prescribed records and reports, and periodical visits to the premises to insure that only taxpaid liquor is being dealt in; that the dealer has paid the occupational taxes imposed on the business; that the liquor is not being sold or shipped into dry states for unlawful delivery or use contrary to the Act ${ }^{88}$ to enforce the Twenty-first Amendment and that the fair trade practice provisions of the Federal Alcohol Administration Act are being observed. The provisions of the latter act do not extend to retailer establishments but are binding upon all producers as well as wholesale distributors. Under the terms of the Federal Alcohol Administration Act and regulations promulgated thereunder, it is made unlawful for producers and distributors, subject to specified jurisdictional limitations, to create exclusive outlets or tied-houses, to sell on consignment or conditional sale, to indulge in commercial bribery, or to label or advertise falsely. All these provisions of the Federal Alcohol Administration Act which relate to the merchandising of alcoholic beverages are administered by the Alcohol Tax Unit district supervisors.

(g) Industrial alcohol-No treatment of the subject of government supervision over the alcoholic beverage industries would be complete without a reference to the supervision exercised over the production, denaturation and distribution of alcohol for industrial uses. The regulation of the nonbeverage alcohol industry occupies much of the time and attention of the Alcohol Tax Unit personnel. The importance of careful supervision over the industrial field is apparent from the fact that alcohol for industrial purposes is released by the Government free of tax, and unless carefully supervised, and restricted to legitimate operators, would be easily diverted into beverage channels, with resulting losses of revenue. There are approximately forty industrial alcohol plants in operation in the United States, producing more than $13^{0}$ million gallons of alcohol annually for use in industry. Most of this alcohol is denatured with substances which make it unsuitable for beverage purposes, but do not destroy its suitability for use in manufacturing processes, or in the manufacture of industrial products. Completely denatured alcohol, which is so treated, under government permit, as to be made wholly unfitted for beverage use, may be sold and used with practically no limitations and without permit and bond. This product is practically all used as an anti-freeze in automobile radiators. Specially denatured alcohol on the other hand is so treated with denaturants as to permit of its use in a greater number of specialized arts and industries than is possible in the case of completely denatured alcohol. This type of alcohol is used directly or indirectly in the production of chemicals, drug extracts, pharmaceuticals, external medicinal preparations, cosmetics, shellacs, varnishes, lacquers, plastics and other industrial products. Millions of gallons of it are used in the production of smokeless powder and other

${ }^{07}$ I. R. C. $\$ 3252$.

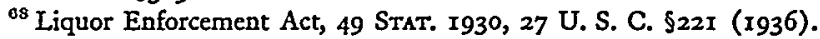


products indispensable to national defense. Because of the character of the denaturing material used in specially denatured alcohol, it is more readily convertible into a beverage, through the removal of denaturants, than is the completely denatured product. It is thus necessary for the protection of the revenue, to be assured that this type of alcohol is in fact used for the purposes for which intended. All users of specially denatured alcohol, of whom there are more than four thousand in the United States, as well as all industrial alcohol plants, denaturing plants, and dealers, are required to secure permits from the Alcohol Tax Unit, conditioned upon the observance of applicable revenue laws. These permits are revocable, after hearing, in cases where it is found that the producer, denaturer, dealer or user has diverted the product to a beverage or other unauthorized use, and taxes are assessed and collected, at the beverage rate, on the quantities diverted.

\section{Hearing Procedure}

\section{Applications for Permits and Proceedings to Suspend, Annul or Revoke}

An application for basic permit must be issued to cover each individual plant or premises where any of the businesses covered by the Federal Alcohol Administration Act permit system is engaged in, except that in the case of importers and wholesalers, one basic permit, issued in the district wherein the applicant has his main office or place of business, authorizes the general conduct of business throughout the United States in branch offices and places of business. All permits under the Federal Alcohol Administration Act, as well as all permits covering the manufacture, denaturation and use of industrial alcohol under the revenue laws, are issued by the district supervisors of the Alcohol Tax Unit. Due to the decentralization of the basic permit system covering the production and distribution of beverage spirits, following the abolition of the Federal Alcohol Administration, drastic revisions in procedure were made necessary. In order to avoid having district supervisors operate under one set of rules in issuing and revoking industrial alcohol permits, and another set of rules covering the beverage permit field, the procedure in effect for many years with respect to the issuance and revocation of industrial alcohol permits was extended to cover permits under the Federal Alcohol Administration Act, in so far as it could be made applicable, and in so far as such procedure was not in conflict with the Federal Alcohol Administration Act. ${ }^{69}$

Upon receipt of applications for permits executed in proper form, the district supervisor assigns inspectors to make a thorough investigation of the applicant to determine his qualifications to hold a permit, such investigation including an inquiry into the applicant's past history, his criminal record, if any, his financial standing, reputation, trade connections, and such other matters as may reflect upon his integrity and likelihood to conduct the business lawfully. In the case of industrial alcohol permits, the supervisor, upon review of the investigating officer's report, determines what action should be taken upon the application, and either approves or disapproves the permit application, without the formality of advance notice and opportunity for

${ }^{\circ 0}$ U. S. Treas. Dec. 4982 (July XI, I940). 
hearing to the applicant. Within fifteen days after receipt of notice of disapproval the applicant may apply in writing to be heard by the supervisor, or his authorized agent, in support of his application. In view of the specific requirement of the Federal Alcohol Administration Act that the applicant be afforded due notice and opportunity for hearing on the application, in advance of adverse action thereon, the procedure resorted to in connection with the issuance of industrial alcohol permits is modified in the case of beverage permits to the extent indicated.

Should application be made for a hearing, the district supervisor notifies the applicant of the time and place of hearing, which must be held within thirty days after receipt of the request, unless continued for cause. At all hearings upon permit applications the applicant is required to assume the burden of proof in establishing his fitness for a permit, and must go forward with his case in advance of the introduction of any testimony by the district supervisor or his representative. ${ }^{70}$ The Deputy Commissioner in charge of the Alcohol Tax Unit, or the district supervisor in charge of the field office, designates in writing some official or employee as hearing officer, to hold and conduct hearings upon permit applications and upon proceedings to suspend, annul or revoke permits. These appointments are usually general in nature and are not made, except in special instances, to cover individual proceedings. All notices of contemplated denial of beverage permits, and all orders to show cause why beverage or industrial permits should not be suspended or revoked, are signed by the district supervisor. The citation, in revocation, suspension or annulment cases, must contain a statement of the acts charged as having been committed by the permittee and constituting the grounds upon which the proceedings are based.

In cases involving applications for beverage permits under the Federal Alcohol Administration Act the notice of contemplated denial must contain a statement of the grounds upon which the supervisor intends to rely in acting adversely upon the permit application. Service of the citation is made by mailing a copy thereof to the applicant or permittee, as the case may be, by registered mail or by having the same served personally by an agent or inspector of the Alcohol Tax Unit. A certificate of mailing and the registry return card, or certificate of the officer making personal service, must be filed as a part of the record in the case. In cases involving revocations of industrial alcohol permits the hearing must be held within fifty miles of the place where the acts constituting the violation are alleged to have occurred. Although this requirement is not made specifically applicable to hearings involving permits under the Federal Alcohol Administration Act, it is likely that the same requirement will be made applicable to such hearings, in view of the decentralization of the permit system and the vesting of authority in district supervisors to issue, suspend, annul and revoke such permits. After the service of a citation the permittee may, if he desires, file a stipulation with the designated hearing officer waiving the taking of evidence on the charges contained in the citation and agreeing that an order be entered denying, suspending, annulling or revoking the permit, as the case may be.

\footnotetext{
${ }^{30}$ For a discussion of this procedure see Yudelson v. Andrews, 25 F. (2d) 80 (C. C. A. 3d, 1928); Chicago Grain Products Co. v. Mellon, I4 F. (2d) 362 (C. C. A. 7th, 1936).
} 
The evidence introduced at the hearing, either on behalf of the Government or the respondent, may consist of affidavits, depositions, duly authenticated copies of records and documents, and oral testimony of witnesses. However, affidavits may not be used if the personal attendance of the affiant as a witness is reasonably possible, and such a showing must be made in advance of the admission of the affidavit in evidence. When it appears that the personal attendance of the witness is not reasonably possible, or that the witness will not execute an affidavit or sign a written statement, the official report of the agent or inspector, showing the substance of the information conveyed to him by the absent witness, may be introduced in evidence upon identification by the agent or inspector. ${ }^{71}$ Unless waived by both parties, a stenographic record is made of the testimony and proceedings, including stipulations and admissions of fact but not arguments of counsel. A transcript of the proceedings must be made in all cases where liability for taxes are involved, and in all cases where desired by the respondent for use in court proceedings to review the supervisor's action. In cases where the representatives of the government and the respondent agree upon a summary narrative of the testimony in lieu of the report thereof, the summary narrative is reduced to writing and has the same force and effect as if the testimony were reported in detail.

At the conclusion of the testimony the hearing officer may hear arguments of counsel and may limit the time of such arguments at his discretion, and may also allow briefs to be filed on behalf of either party and may fix a time within which the same may be filed. Within a reasonable time after the conclusion of the hearing, the hearing officer must render written findings of fact, stating the issues of fact involved in the hearing, his conclusions thereon from the evidence adduced, and a summary of the evidence offered by both parties. Such findings, together with the transcript of the record, are forwarded to the district supervisor for review and action. Prior to July $\mathrm{I}$, I940, under regulations then in effect governing hearings under the Federal Alcohol Administration Act, a copy of the hearing officer's report was required to be served upon the respondent or his representative, and provision was made for the filing of written exceptions to the hearing officer's report within ten days after service. On the basis of these exceptions, oral arguments were had before the Administrator,

${ }^{71}$ The Comptroller General ruled November 29, I924 (4 Comp. Gen. Op. 499), "Answering the specific question presented I have to advise that there appears to be no authority of law for the payment of expenses incident to securing the attendance of witnesses at hearings conducted by the Bureau of Internal Revenue for the purpose of determining whether permits issued under the National Prohibition Act should be revoked or reduced." Industrial alcohol permits were issued under the National Prohibition Act, and the substance of the National Prohibition Act permit requirements, in respect to industrial alcohol, was carried forward in $\$ 6$ of the Liquor Law Repeal and Enforcement Act which appears as $\$ 3114$ (a) of the Internal Revenue Code. In Meinwald v. Doran, 60 F. (2d) 261 (E. D. N. Y. I932) the Court said, "Congress has failed to provide subpoena powers, and therefore the hearings are placed in the same category as other administrative hearings under other laws, in which, where the personal attendance of witnesses cannot be procured, secondary evidence may be received." See also Ossam v. Moss, 44 F. (2d) 845 (E. D. N. Y. 1930); Doran v. Kaier, 60 F. (2d) 259 (C. C. A. 3d, 1932). The applicability of this procedure to permits under the Federal Alcohol Administration Act is doubtful, in view of the fact that $\$ 9$ of the Federal Trade Commission Act (38 STAT. 772 [1914], I5 U. S. C. $\$ 49$ ), which gives the power to require by subpoena the attendance and testimony of witnesses, is made available by Congress to enforce the Federal Alcohol Administration Act (27 U. S. C. $\$ 202(\mathrm{~g})$ ). 
who was then charged under the statute with the responsibility for issuing and revoking permits, and final action by him in the proceedings was deferred until the conclusion of the argument. This procedure has now been dispensed with. Upon receipt of the hearing officer's report, the district supervisor reviews the record and acts thereon in accordance with his best judgment, either disapproving the permit application or revoking, suspending, or annulling the basic permit, as the case may be, or dismissing the proceedings if warranted. If the supervisor does not concur in the findings or conclusions of the hearing officer, after consideration of the record of the evidence taken at the hearing, he must make such findings and order as in his opinion are warranted by the law and the facts in the case. A copy of the order of the supervisor and of his findings of fact, if any, are forwarded to the respondent or his attorney of record in the proceedings.

Within twenty days after service of the order the respondent may file an application with the supervisor for a reconsideration of the order, on the ground that it is contrary to law, or not supported by the evidence, or because of newly discovered evidence which the respondent, with due diligence, was unable to produce at the hearing. The supervisor may hear the application personally on a day fixed by him, or refer it for hearing to a board of review, consisting of not more than three persons designated by him. Following such review the supervisor may either affirm or modify the order previously made, or may vacate and set aside the order and dismiss the proceedings, or order a new hearing. After final order by the supervisor, and in order to insure uniformity of administrative action, the Deputy Commissioner of Internal Revenue in charge of the Alcohol Tax Unit, may, in his discretion, entertain an appeal from the supervisor's order, if filed within ten days from the date of the order. The petition for review must set forth facts tending to show action of an arbitrary nature, or a proceeding and action contrary to law and regulation.

Two modes of review by the courts are provided for, one applicable to industrial alcohol permits, and the other applicable to beverage permits issued under the Federal Alcohol Administration Act. In cases involving industrial alcohol permits, the applicant or permittee, in the event of disapproval of the permit application, or the revocation of a permit by the district supervisor, or Deputy Commissioner, may have a review of the decision in the United States district courts. The court upon such review may affirm, modify or reverse, as the facts and the law in the case may warrant. ${ }^{72}$ In cases involving permits under the Federal Alcohol Administration Act appeals from orders denying, suspending, revoking or annulling permits may be taken by filing an appropriate petition in a circuit court of appeals. ${ }^{73}$

The procedure followed by the district supervisors in issuing, suspending and revoking permits for the manufacture, storage, procurement and transportation of bottles, designed or intended for use in the sale at retail of distilled spirits, is substantially the same as the procedure applicable to other permits issued under the internal revenue laws and the Federal Alcohol Administration Act. There is, however, no

$z 2$ I. R. C. $\$_{3114}(\mathrm{a})$, (b), (c).

${ }^{73}$ Procedure discussed supra p. 576. 
provision made by statute for a review of the supervisor's or Deputy Commissioner's action in denying, suspending or revoking such permits.

\section{Promulgation of Regulations}

The rule-making powers of the Treasury Department with respect to liquor are perhaps more extensive than in any other field of government activity, because the liquor industry, from the revenue as well as the social standpoint, is the most thoroughly regulated and carefully supervised of all the industries. All needful procedure governing the details of operation cannot be spelled out in acts of Congress, with the result that the executive branch is vested with broad regulatory powers. In the exercise of these powers it is pertinent to note that Congress, with one exception, has never seen fit to require that liquor regulations be made the subject of public hearings, or that the regulations prescribed be subject to judicial review. The exception is the Federal Alcohol Administration Act, which deals with the regulation of trade practices, as distinguished from revenue collection. This act requires that reasonable public notice and opportunity for hearing be afforded to interested persons prior to prescribing any regulations governing labeling, advertising or trade practices, thus following a modern trend also evidenced in recent acts of Congress, such as the Fair Labor Standards Act, ${ }^{74}$ the Bituminous Coal Act of $1937^{75}$ and the Food, Drug and Cosmetic Act. ${ }^{76}$ The Federal Alcohol Administration Act, however, makes no provision for judicial review of regulations issued after public hearing.

Although the Alcohol Tax Unit has not undertaken to promulgate any labeling, advertising or trade practice regulations since it became charged with enforcing the Federal Alcohol Administration Act, it is assumed that the procedure to be followed in drafting such regulations and in holding public hearings thereon will follow closely the procedure heretofore followed by the Federal Alcohol Administration. Notice of public hearing upon proposed regulations has usually been given to parties in interest at least thirty days in advance of the hearing. No attempt is made in the notice of hearing to paraphrase the exact language of the regulation that is proposed to be adopted. The proposed regulation is described in the hearing notice in general terms, with stress upon the ultimate objective rather than phraseology. Notice of the hearing is published in the Federal Register, and copies thereof are also mimeographed and distributed to members of the industry who, because of the nature of their business, are thought to be interested in the subject matter. Hearings are conducted informally, in much the same manner as legislative hearings before Congressional committees. Parties desiring to be heard are permitted to read prepared statements and file for the record any statistical material or other written matter which may have a bearing on the subject. Witnesses are not sworn nor permitted to be cross-examined by parties at the hearing whose views are in conflict with those expressed by the witness. However, all witnesses are ordinarily examined at length by the government officers conducting the hearing. After the close of the hearing

${ }^{74} 52$ STAT. 1060, 29 U. S. C. $\$ \$ 15 I$ et seq. (1938).

${ }^{75}$ 5O STAT. 72, I5 U. S. C. $\$ 829$ (I937).

${ }^{70} 52$ STAT. I040, 2 I U. S. C. $\$ \$ 301$ et seq. (1938). 
opportunity is afforded to file briefs within a specified period, usually thirty days. The briefs so filed are studied in conjunction with the stenographic transcript of the hearing record, and digests of the testimony, exhibits and briefs are prepared for purposes of convenience. As to all future regulations promulgated under the Federal Alcohol Administration Act the Deputy Commissioner of Internal Revenue, with the approval of the Commissioner of Internal Revenue and the Secretary of the Treasury, will determine the course of action to pursue, and following such determination, will promulgate regulations with the approval of the Commissioner and Secretary. All regulations are published in the Federal Register and copies thereof mailed to parties in interest and permit holders affected thereby. The policy is generally pursued, in connection with changes in existing regulations, of making the effective date of amendments sufficiently in advance to allow for trade adjustments.

In promulgating regulations under the internal revenue laws the staff of the Deputy Commissioner in charge of the Alcohol Tax Unit, including officers in the field, occasionally encounters weaknesses in existing regulations, and where such weaknesses are discovered appropriate amendatory regulations are issued. As new acts are passed by Congress it becomes necessary to issue regulations to carry the provisions of the new law into effect, and amendments to existing regulations to bring the same into conformity with the procedure made necessary by new legislation. In all of these matters the Deputy Commissioner of Internal Revenue in charge of the Alcohol Tax Unit, upon determining the course of action to pursue, submits necessary regulations to the Commissioner of Internal Revenue and the Secretary of the Treasury, for approval before promulgation. Although it is not necessary under the law to afford to interested parties any opportunity for public hearing in advance of prescribing internal revenue regulations, the custom is sometimes pursued of submitting drafts of proposed regulations, informally, for criticism of industry members or their representatives. This is usually accomplished by soliciting the viewpoints of officials and attorneys for existing trade associations in the beer, wine or spirits field.

\section{IMPORTS AND EXPORTS}

The duties of the Treasury Department Bureau of Customs, with respect to the importation of liquor, are merely incidental to the broad functions of the Bureau in controlling the entry of foreign merchandise into the United States. The procedure applicable to liquor imports differs from the procedure applicable to other commodities, only to the extent that restrictions imposed by law on the importation of liquor are not imposed on other commodities. For example, in the case of alcoholic beverages the importer is required to hold a permit under the Federal Alcohol Administration Act to engage in the business of importing. Consequently customs authorities will not permit beverage liquor, imported for sale or other commercial purposes, to be entered into customs for domestic consumption unless the person seeking to make the entry holds the necessary permit. All restrictions domestically imposed with respect to the labeling, marking, stamping, and size and fill of liquor containers are made equally applicable to imported liquors. Customs officers at the 
various ports of entry must therefore be satisfied before releasing liquor from customs custody that these requirements are met. All imported distilled spirits in containers of $1 / 2$ pint up to one gallon must be packaged in liquor bottles which have blown therein the required indicia; internal revenue strip stamps, unless affixed by the exporter abroad, under regulations authorizing the same, must be attached to each bottle while in customs custody; restrictions against the importation of empty liquor bottles must be enforced; certificates of origin executed by foreign government officials must be presented to vouch for the genuineness of French Cognac and Scotch, Irish and Canadian whisky; similar certificates must be presented to cover importations of whisky of American type; statement of age appearing upon the labels of imported whiskies, brandies and rums must be authenticated by foreign government certificates as to age accompanying each importation; the invoices covering liquor shipments from abroad must be certified by American consular officers in the same manner as invoices covering shipments of other merchandise; distilled spirits in bulk containers may not be released except to authorized receivers; the internal revenue tax and customs duties must be collected and deposited. ${ }^{77}$

In addition to enforcing the restrictions applicable to commercial shipments of liquor, customs collectors control importations of liquor in the baggage of incoming nonresidents, and residents of the United States returning from abroad. Although provision is made for the free entry of property up to \$roo.00 in value in the possession of returning residents, there may not be included in such exempt property more than one gallon of alcoholic beverages. Adult nonresidents are allowed exemption only on one quart of alcoholic beverages.

Congress makes provision for the exportation of alcoholic beverages, free of tax, under regulations requiring close supervision by the Alcohol Tax Unit of the Bureau of Internal Revenue, and by the Customs Bureau. ${ }^{78}$ All distilled spirits, wine and malt beverages withdrawn free of tax for export, after being marked and branded in a distinguishing manner, are passed through the collector of customs at the port of exportation. ${ }^{79}$ The exporter is required to give bond to insure that the product after exportation will not be relanded in the United States. Provision is also made for the exportation of distilled spirits and wines, upon which the internal revenue tax has been paid, if bottled under supervision especially for export, with provision for refund of the tax upon proof of landing in a foreign port.

\footnotetext{
${ }^{77}$ The prevailing rates of duty on alcoholic beverage imports, which, except in the case of beer, are in addition to the internal revenue taxes, are: whiskey less than four years old $\$ 5.00$ per proof gallon; whiskey four years or more old $\$ 2.50$ per proof gallon; beer 50 cents a gallon; rum imported in containers of more than one gallon $\$ 5.00$ per proof gallon; rum imported in containers of one gallon or less $\$ 2.50$ per proof gallon; gin, brandy, cordials, liqueurs and bitters $\$ 2.50$ per proof gallon; champagne and other sparkling wine $\$ 3.00$ a gallon; vermouth, and still wines of $14 \%$ or less alcohol, in containers of more than I gallon $\$ 1.25$ per gallon; still grape wines of $14 \%$ or less alcohol in containers of 1 gallon or less 75 cents per gallon; vermouth in containers of I gallon or less $\$ .621 / 2$ per gallon; wines over $14 \%$ alcohol $\$$ I.25 a gallon. All these rates are reduced $20 \%$ on products of Cuba. In the case of distilled spirits imported at less than roo proof, the same duty is collected as for 100 proof spirits.

${ }^{78}$ I. R. C. $\$ \$ 2885,3037$, and 3151 .

${ }^{29}$ According to the Bureau of Foreign and Domestic Commerce there were imported into the United States during I939: Ir,422,404 proof gallons of distilled spirits, 3,936,899 gallons of wine, and I,984,272 gallons of beer. During the same period there were exported from the United States: 284,432 proof gallons of distilled spirits, 86,5 I9 gallons of wine, and 708,552 gallons of beer.
} 